\title{
ESTUDIO REOLÓGICO EN PUENTES ARCOS DE HORMIGÓN
}

\section{Hermógenes Rosas Rodríguez}

\section{RESUMEN}

En este artículo se representa el estudio numérico del comportamiento de las deformaciones en el tiempo debidas a los efectos reológicos (retracción y fluencia) del hormigón. Estas deformaciones se presentan en estructuras de gran envergadura que trabajan a compresión, como pilas altas en puentes, losas continuas pretensadas, puentes arcos y otros. En este estudio se consideró un puente arco de $105 \mathrm{~m}$ de luz, flechas de 15 y $30 \mathrm{~m}$ de altura, y relaciones luz/flecha iguales a 3,5 y 7. En la modelización se supone que el arco fue construido por fases, como los puentes en voladizos sucesivos. Cada tramo es de $15 \mathrm{~m}$ de longitud y se analiza, por simetría, las deformaciones en tres puntos situados en los riñones y uno ubicado en la clave del arco. El método utilizado es el de los elementos finitos, con las formulaciones establecidas en el Código Modelo. Los resultados muestran que los momentos flectores positivos disminuyen en el tiempo. En cambio, los negativos aumentan y las deformaciones elásticas son importantes antes del cierre en la clave del arco. Finalmente, las deformaciones debidas a retracción y fluencia evolucionan significativamente durante los tres primeros meses de edad del hormigón.

Palabras Clave: Hormigón, Retracción, Fluencia, Puentes Arcos y Deformaciones. 